\title{
Characterization and Treatment of Titanium Dioxide via Ultrasonic Process with Melastoma malabathricum as Sustainable Sensitizer for Photovoltaic Solar Cell
}

\author{
Anika Zafiah M. Rus, ${ }^{1}$ Nur Munirah Abdullah, ${ }^{1}$ and M. F. L. Abdullah ${ }^{2}$ \\ ${ }^{1}$ Department of Materials and Design Engineering, Faculty of Mechanical and Manufacturing Engineering, Malaysia \\ ${ }^{2}$ Department of Communication Engineering, Faculty of Electrical and Electronic Engineering, Universiti Tun Hussein Onn Malaysia, \\ 86400 Parit Raja, Malaysia \\ Correspondence should be addressed to Anika Zafiah M. Rus; zafiah@uthm.edu.my
}

Received 31 October 2012; Revised 13 January 2013; Accepted 14 January 2013

Academic Editor: José M. López-de-Luzuriaga

Copyright (c) 2013 Anika Zafiah M. Rus et al. This is an open access article distributed under the Creative Commons Attribution License, which permits unrestricted use, distribution, and reproduction in any medium, provided the original work is properly cited.

\begin{abstract}
Generation from the existing commercial devices costs about ten times more than the conventional methods. Therefore, this paper presents a thin-film dyed solar cell (DSC) of natural dyes from Melastoma malabathricum fruits which consist of the carbonyl and hydroxyl groups of anthocyanin molecule that influences the performance of photosensitized effect due to its bound on the surface of filler. Experimental results comparing engineering grade ( $>99 \%$ purity) of metal oxide; U1 and U2 with treated metal oxide; U3 and $\mathrm{U} 4$ using ultrasonic process, which is to break the particle agglomeration from $0.37 \mu \mathrm{m}$ down to $0.15 \mu \mathrm{m}$; this treatment led to a more "sponge-like" consistency with high porosity, enabling enhanced absorption and anchorage of the dye sensitizer. The microstructures of metal oxide were observed using Field Emission Scanning Electron Microscope (FESEM) and Atomic Force Microscope (AFM). Along with the highest performance of $I-V$ measurement given by $\mathrm{U} 4$ with open circuit, $V_{\mathrm{oc}}=0.742 \mathrm{~V}$, short circuit, $I_{\mathrm{sc}}=0.36 \mathrm{~mA}$, fill factor, $\mathrm{FF}=57.012$ gives $0.039 \%$ efficiency the examples for the first outdoor application upon sunlight illumination of such DSC were also reported. Therefore, this ultrasonic treatment and novel dye from Melastoma malabathricum fruit are reliable to be used for further application.
\end{abstract}

\section{Introduction}

Development of the dye solar cell for mass production mainly depends on three crucial key points, "acceptable efficiency," "low manufacturing cost", and "environmental friendly" The absorption spectrum of the dye and the anchorage of the dye to the surface of metal oxide are important parameters in determining the efficiency of the cell [1]. The sensitization of wide band gap semiconductors using natural pigments is usually ascribed to anthocyanins, found in fruits $[2,3]$, flowers [4], and leaves of plants which have advantages over chlorophyll as dye solar cell sensitizer [5-8]. As for the metal oxide, manipulating its physical and chemical properties can lead to widespread environmental applications [9-11]. In 2010, Jin and Suslick [12] summarized that ultrasonic approach has more advantages over conventional methods in the synthesis of nanostructured materials [13] such as metals, alloys, oxides [14], sulfides, carbides, carbons, polymers, and even biomaterials. The versatility of the ultrasonic process where perform in a solvent form more uniform size distribution, contribute to higher surface area, faster reaction time, and improved phase purity. Herein the summation of the "photon-to-electrical" converter mechanism is given: anode:

$$
\begin{aligned}
& \mathrm{TiO}_{2}\left|\mathrm{~S}+h v \longrightarrow \mathrm{TiO}_{2}\right| \mathrm{S}^{*} \text { absorption } \\
& \mathrm{TiO}_{2}\left|\mathrm{~S}^{*} \longrightarrow \mathrm{TiO}_{2}\right| \mathrm{S}^{+}+e_{\mathrm{cb}} \quad \text { electron injection } \\
& \mathrm{TiO}_{2}\left|\mathrm{~S}^{+} \longrightarrow e_{\mathrm{cb}}+\mathrm{TiO}_{2}\right| \mathrm{S} \\
& \mathrm{TiO}_{2}\left|\mathrm{~S}^{+}+\frac{3}{2} I^{-} \longrightarrow \mathrm{TiO}_{2}\right| \mathrm{S}+\frac{1}{2} I_{3}^{-} \quad \text { dye regeneration }
\end{aligned}
$$


cathode:

$$
\begin{aligned}
& \frac{1}{2} I_{3}{ }^{-}+e_{\mathrm{Pt}} \longrightarrow \frac{3}{2} I^{-} \quad \text { electrolyte regeneration } \\
& e_{\mathrm{Pt}}+h v \longrightarrow 3 I^{-}
\end{aligned}
$$

The conversion of light into electric starts when the light (photon) hits the surface of electrode and absorbed by the dye molecules which is attached to the high surface area, a sponge-like oxide thin film. As a result, the dye is oxidized $\left(\mathrm{S}^{*}\right)$ and photoexcitation occurs. Photoexcitation is the state where the electron from the valence band is injected to the conduction band of the oxide, leaving a hole $\left(\mathrm{S}^{+}\right)$ behind. Excited state conduction band electrons and valence band holes can recombine and dissipate the input energy as heat, get trapped in metastable surface states, or react with electron donors and electron acceptors adsorbed on the semiconductor surface or within the surrounding electrical double layers of the charged particles [15].

Next, the excited electrons are transported by diffusion along the oxide thin-film network towards the external conducting glass and consequently reach the platinum counter electrode through the external load [16]. At the time being, the oxidized dye $\left(\mathrm{S}^{+}\right)$is back to its normal state $(\mathrm{S})$ as it received electron from the electrolyte which is usually containing a redox system of an iodide/triiodide couple. In turn, the electrolyte is regenerated via the electron from the external load.

In this paper, the technique of preparing dye solar cell using engineering grade metal oxide of titanium dioxide, $\mathrm{TiO}_{2}$ (>99\% purity) will undergo ultrasonic process, and natural dyes extracted from a local fruits as sensitizer were disclosed to develop a single cell of dye solar cell with acceptable efficiency.

\section{Assembling and Characterization of DSC}

The extraction of dye from the plant material was carried out in lab scale quantity comprised of soaking, dried, cleaned, and pulverized plant material followed by a second step of heating up dyestuff at certain temperature. The solution was further filtered to obtain the dyestuff. This process was adopted from Lee et al. [16] and Agarwal and Ghaziabad [17].

Engineering grade; $99 \%$ purity of $\mathrm{TiO}_{2}$ was grinded in a mortar and pestled with few drops of surfactant resultant uniform and lump-free paste, namely, U1 and U2. The metal oxide mixture was placed uniformly over a slide in a rapid motion. The slides were sintered over a hot plate until a transition from white to a brownish colour has been observed. Once the film has cooled, the slide was placed in a Petri dish filled with sensitizing dye for a few minutes.

Meanwhile for the treated metal oxide, U3 and U4, the ultrasonic process was carried out using clamp-on tubular reactor with tube diameter of $60 \mathrm{~mm}$ and length of $580 \mathrm{~mm}$ at certain frequency (trial frequency at $18.520 \mathrm{kHz}$ ) as in Table 1. The U3 and U4 electrode preparation method goes the same as $\mathrm{U} 1$ and $\mathrm{U} 2$. Then, counter electrodes were prepared using carbon black.

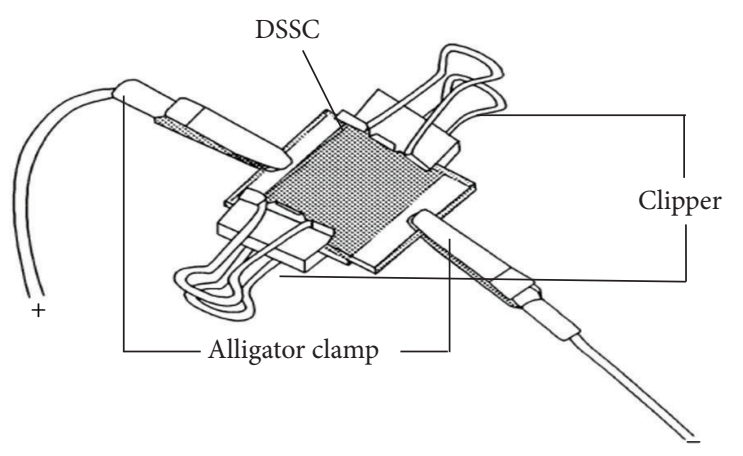

FIGURE 1: Single cell of assembled dye solar cell.

The cells were assembled by sandwiching the glass together. Then 2-3 drops of an electrolyte are placed between the two electrodes for capillary action. The sandwiching of the electrodes is an offset so that each one has a small exposed portion.

An alligator clamp was attached on the exposed portion as shown in Figure 1. The negative clamp goes to the metal oxide/sensitizer plate and the positive clamp goes to the carbon black plate. The assembled dye solar, surface morphology of the $\mathrm{TiO}_{2}$ thin film was observed using Field Emission Scanning Electron Microscope (FESEM), surface profiler, and Atomic Force Microscope (AFM). The assembled solar cell was tested upon 1 Sun of light illumination using Solar Simulator for $I-V$ characteristic to calculate the cells efficiencies.

\section{Results and Discussion}

Particle Size Analyzer (PSA) was used to examine the particle size of treated $\mathrm{TiO}_{2}$ via ultrasonic process. It is predicted that the particle size of the $\mathrm{TiO}_{2}$ or the particle agglomeration is breaking down to smaller scale than its original size. This size has been approved by the XRD patterns as shown in Figure 2. All the sharp peaks assignable to the anatase phase and also detected very small peaks in which to be rutile phase were clearly observed. This observation is comparable with the findings of Sundström (Ed.) as reported in 2009 [18]. The broaden peaks (compared to their originals) which indicate a decreased particle size obviously refer to the treated $\mathrm{TiO}_{2}$ via ultrasonic process. The particle size distribution of $\mathrm{TiO}_{2}$ reduces from $0.37 \mu \mathrm{m}$ down to $0.15 \mu \mathrm{m}$ for $10,20,30,40$, 50,60 minutes, respectively. It is positively showed that 10 minutes of ultrasonic process with frequency of $18.520 \mathrm{kHz}$ possibly break up the particle size of $\mathrm{TiO}_{2}$ agglomerates.

3.1. Microstructure of $\mathrm{TiO}_{2}$ Coated Glass. A more accurate view of the film surface can be taken with FESEM whereby electrons are accelerated towards the sample, and upon collision, secondary electrons emitted from the surface are detected. Figures 3(a), 3(b), 4(a), and 4(b), respectively, display the regularity of the film on a larger scale. The average size of the $\mathrm{TiO}_{2}$ particles along with pores can be calculated 
TABLE 1: Condition process for clamp-on tubular reactor.

\begin{tabular}{lcccccccc}
\hline $\begin{array}{l}\text { Freq } \\
(\mathrm{kHz})\end{array}$ & $\begin{array}{c}\text { Sweeping } \\
(\mathrm{kHz})\end{array}$ & $\begin{array}{c}\text { Power } \\
(\%)\end{array}$ & $\begin{array}{c}\text { Max current } \\
(\mathrm{A})\end{array}$ & $\begin{array}{c}\text { PWM period } \\
(\mathrm{s})\end{array}$ & $\begin{array}{c}\text { PWM ratio } \\
(\%)\end{array}$ & $\begin{array}{c}\text { FSWM range } \\
(\mathrm{kHz})\end{array}$ & $\begin{array}{c}\text { FSWM ratio } \\
(\%)\end{array}$ & $\begin{array}{c}\text { FSWM period } \\
(\mathrm{s})\end{array}$ \\
\hline 18.520 & 0 & 50 & 2 & 0.010 & 100 & 0.500 & 50 & 0.010 \\
\hline
\end{tabular}

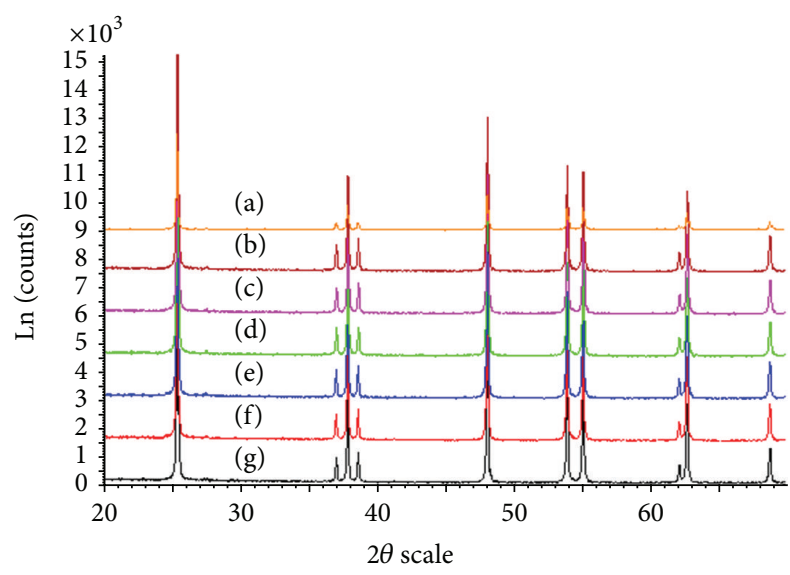

FIGURE 2: XRD patterns of $\mathrm{TiO}_{2}$ powders (a) without ultrasonic process and the rest. (b) 10 minutes, (c) 20 minutes, (d) 30 minutes, (e) 40 minutes, (f) 50 minutes, and (g) 60 minutes, via ultrasonic process, respectively.

as indicated in Figures 3(c), 3(d), 3(e), 3(f), 4(c), 4(d), 4(e), and $4(\mathrm{f})$, respectively.

Figure 4(a) show denser and smoother structure as compared to Figure 3(a). A smaller particle size or smaller particle agglomerates are known to confer a slightly larger surface area, thus a faster reaction rate, and improved phase purity, creating a "sponge-like" high-porosity structure. As a result, more dye sensitizers were absorbed onto the metal oxide film and thus led to an enhanced performance of the photovoltaic solar cell.

The grain boundaries for untreated and treated $\mathrm{TiO}_{2}$ via ultrasonic are shown in Figures 5(a) and 5(b), respectively. Treated $\mathrm{TiO}_{2}$ revealed more uniform size distribution, which contributed to a higher surface area with improved phase purity. This leads to faster reaction time to enhance electron transportation to conduction band. According to Ahmad et al. [21], when the grain size becomes larger, electron movement from particles to other particles improves. This shown in Figure 5(b) as the grain boundaries for treated $\mathrm{TiO}_{2}$ are formed in larger and more homogeneous size as compared to Figure 5(a) for untreated $\mathrm{TiO}_{2}$.

Figure 6 also shows the surface morphology of both films (untreated and treated with ultrasonic) in a 3D form by using Atomic Force Microscope (AFM). The difference between the higher peak and the lower one is represented by the color range shown for both films. It is observed that there is large gap between those higher and lower particles for treated metal oxide with ultrasonic coated film that has smaller particle size with large surface area to volume ratio, and this is where the detrapping and trapping of electrons in metal oxide film take place.
As the particle agglomerates become smaller, more multiple overlappings occur and cause the electron diffusion get slower and simultaneously jeopardize the photovoltaic performance.

However, the optimum particle size shall be assessed; it should not be reduced indefinitely due to the influences of the porosity of the metal oxide layer. As the particle size decreases, the pores also become smaller. The electrolyte has to be able to penetrate the pores and be present where there is an absorbed dye. In addition, larger particles scatter light more effectively, and this has been found to have a positive effect on the performance of the cell $[19,22]$. Illustration of this mechanism can be addressed as in Figure 7.

3.2. Thickness of the Films. In spite of light scattering, the particle size also influences the surface roughness of a film as shown in Figures 8(a) and 8(b). The thin film of untreated $\mathrm{TiO}_{2}$, Figure $8(\mathrm{a})$, gives $0.37 \mu \mathrm{m}$ particle size with $11.4970 \mu \mathrm{m}$ thick while treated $\mathrm{TiO}_{2}$, Figure $8(\mathrm{~b})$, with $0.15 \mu \mathrm{m}$ gives $6.2984 \mu \mathrm{m}$ as its thickness. Note that the treated thin film of $\mathrm{TiO}_{2}$ with a reduced particle size causes reduction in thickness, simultaneously creating more multiple layers up to 42 layers. Meanwhile, the untreated thin film with larger particle size and higher thickness gives only 31 layers. Hence, the photovoltaic solar cell resembles the photosynthetic system in plants more effectively, as a result of its multiple layers.

3.3. Characterization of Natural Dye Sensitizer. In Figure 9, the FTIR spectra show that both commercial dye represented by blackberry dye and local natural dye from Melastoma malabathricum fruit consist of similar groups where at $3333.92 \mathrm{~cm}^{-1}$ the $\mathrm{O}-\mathrm{H}$ stretching vibration, ester/carboxylic stretch $\mathrm{C}=\mathrm{O}$ at $1636.79 \mathrm{~cm}^{-1}$ followed by alkyl group at 2100 to $2200 \mathrm{~cm}^{-1}$, was observed. Here, the interlocking group refers to a group having the function to provide electronic coupling between the chromophoric group of the dyestuff and the conduction band of the semiconductor.

The dye is generally attached to the surface of the semiconductor through the interlocking group. The interlocking group may be at least one selected from the group consisting of a carbonyl group, hydroxyalkyl group, hydroxyl group, sulfonic acid group, carboxyalkyl group, mercapto group, and phosphono group [23]. Due to these interlocking groups, carbonyl and hydroxyl groups presented on anthocyanin molecule as in Figure 10, it can be bound with the surface of $\mathrm{TiO}_{2}$ porous film, which in favor of photoelectric conversion effect [5]. Moreover, anthocyanin from various plants gave different levels of sensitizing performance [24, 25]. 


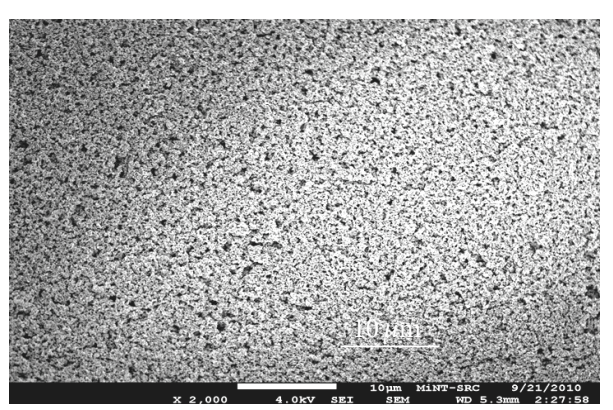

(a)

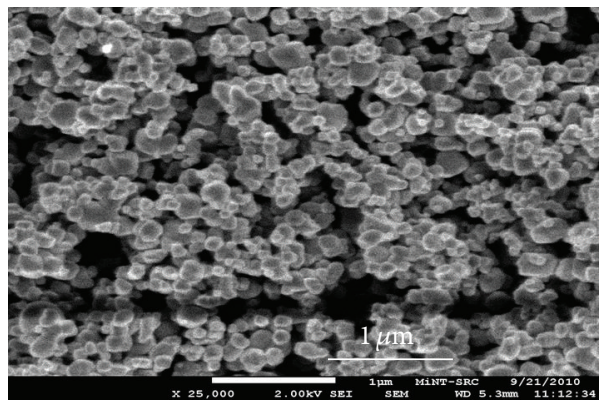

(c)

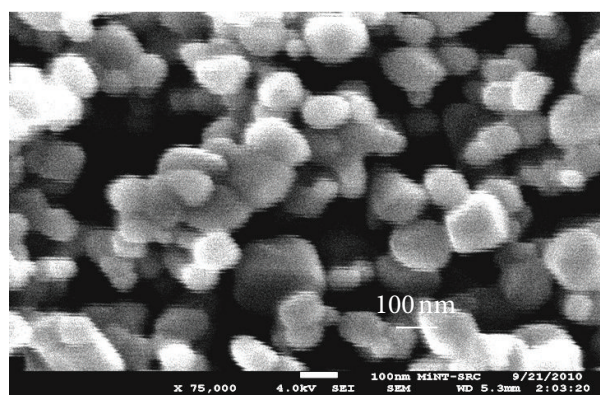

(e)

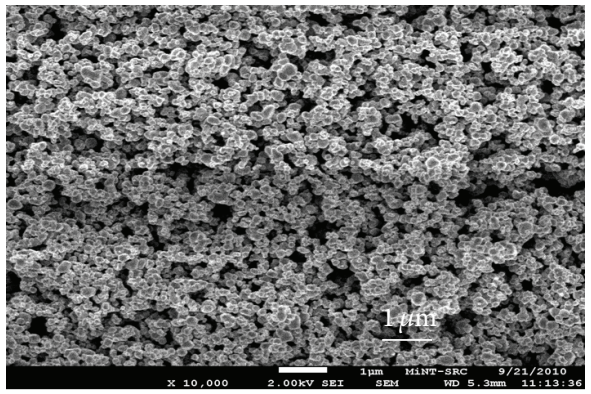

(b)

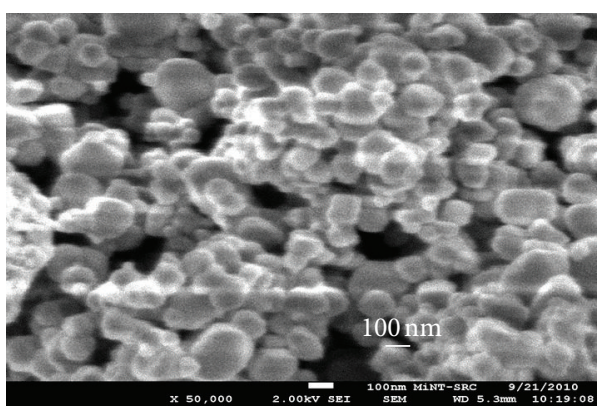

(d)

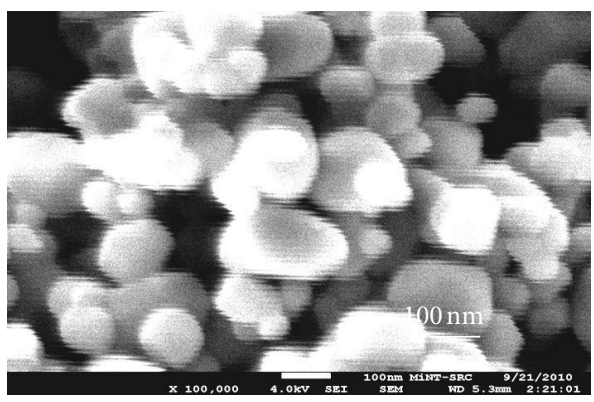

(f)

FIGURE 3: Metal oxide morphology with magnification for untreated $\mathrm{TiO}_{2}$, (a) 2000, (b) 10000, (c) 25000, (d) 50000, (e) 75000, and (f) 100000.

From UV-VIS absorption spectra in Figure 11, dye B shows an advantage result where suggesting it have higher four characteristic broader range of absorption peaks covering the entire visible region $(400-700 \mathrm{~nm})$ especially at $200-$ $600 \mathrm{~nm}$ (the blue-shift phenomenon) compared to dye A. Positively, it is comparable to N719, N3 dyes absorption region [26]. Furthermore, this property enables the photovoltaic solar cell to perform under normal sunlight. Note that the absorptivity is over 1.5 units that is the highest recommended, yet it emphasizes the basic pattern (absorption peaks) of the local natural dye in comparison with the commercial ones.

Giusti and Wrolstad [27] stated that different group exhibits different maximum absorption peak and the shape of the spectrum may give information regarding the number and position of substitutions in anthocyanins. However, variation in dye preparation will cause different natural chemical structure, suggesting that their properties can be tuned (D- $\pi$-A molecular structure) which is advantageous to light harvesting due to its broad feature in UV-vis absorption spectrum.
3.4. Electrical Characteristics. Figure 12 shows the $I-V$ measurement for all the prepared samples using the Solar Simulator. It is predicted that both of the photovoltaic solar cells via ultrasonic treatment in 10 minutes would perform the best. However, based on the graph mentioned later, results show that the photovoltaic solar cell with treated $\mathrm{TiO}_{2}$ and ultrasonic process plus an addition of 4-tert-butylpyridine as additive has the highest current performance while the one without addition, gives the lowest current.

In order to have a clear view, the performance of the photovoltaic solar cell has been calculated theoretically as given, using $I-V$ analysis as shown in Figure 13 [20]. The electrical parameters of all four photovoltaic solar cells using (3) with the extracted Melastoma malabatricum fruit are summarized in Table 2:

$$
\begin{gathered}
\text { fill factor, } \quad \mathrm{FF}=\frac{\left(V_{m} \times I_{m}\right)}{\left(V_{\mathrm{oc}} \times I_{\mathrm{sc}}\right)} \\
\text { efficiency, } \quad \eta=\frac{\left(V_{\mathrm{oc}} \times I_{\mathrm{sc}} \times \mathrm{FF}\right)}{P_{\mathrm{in}}}(\%),
\end{gathered}
$$




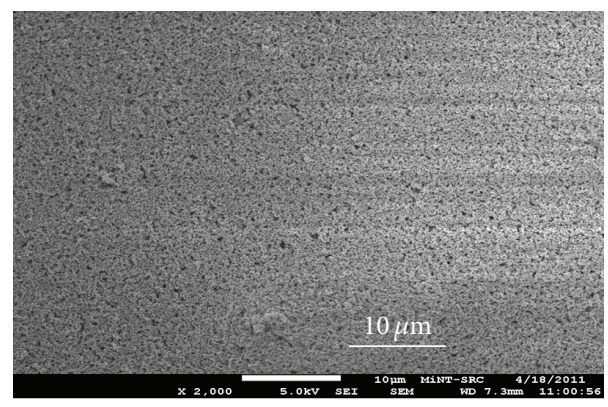

(a)

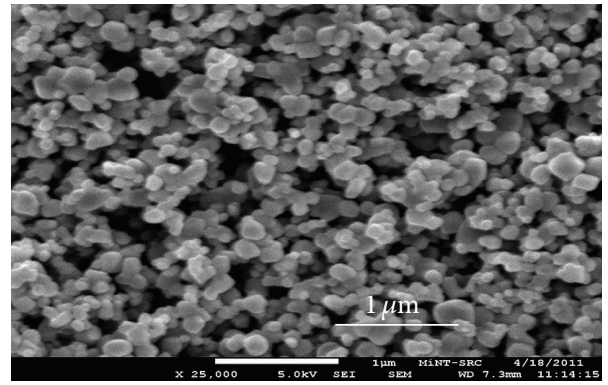

(c)

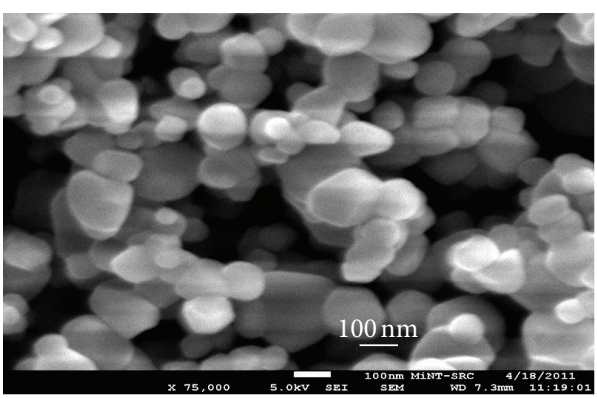

(e)

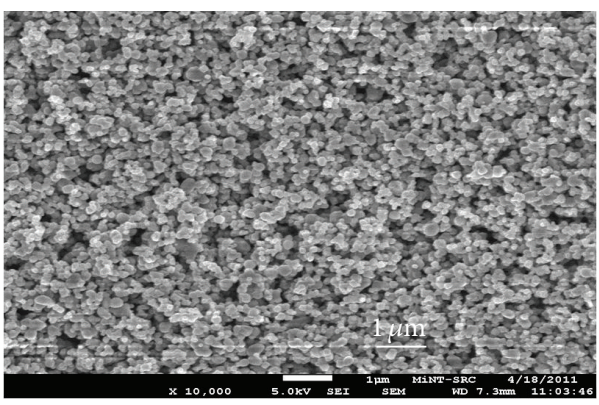

(b)

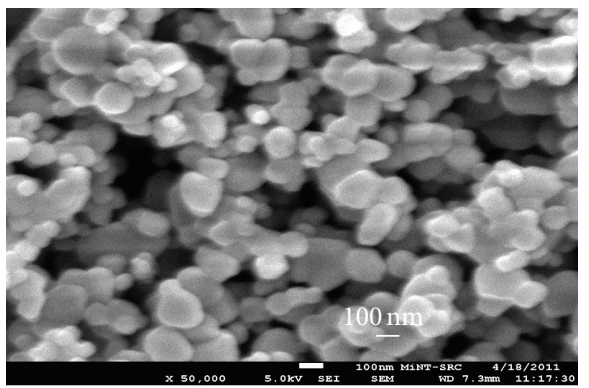

(d)

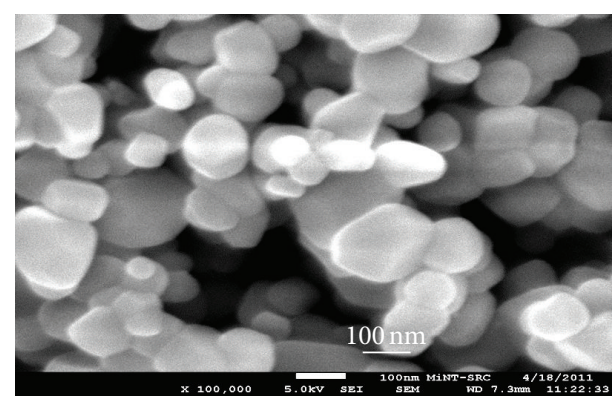

(f)

FIGURE 4: Metal oxide morphology with magnification for treated $\mathrm{TiO}_{2}$, (a) 2000, (b) 10000, (c) 25000, (d) 50000, (e) 75000, and (f) 100000.

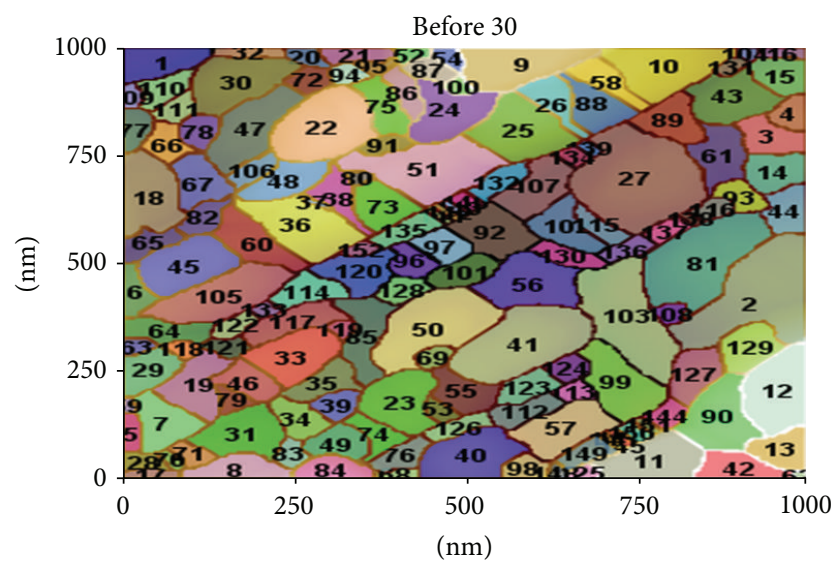

(a)

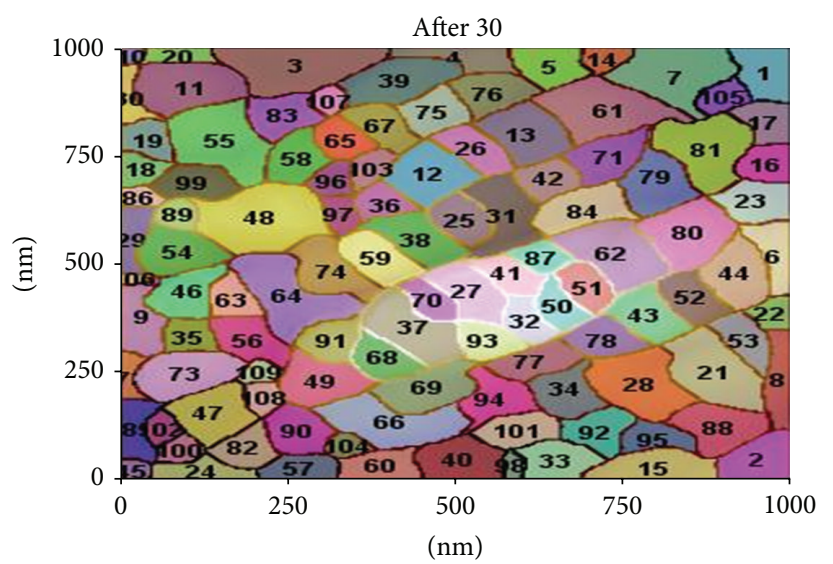

(b)

FIgure 5: (a) The grain boundaries of the film for untreated $\mathrm{TiO}_{2}$ via ultrasonic process. (b) The grain boundaries of the film for treated $\mathrm{TiO}{ }_{2}$ via ultrasonic process. 

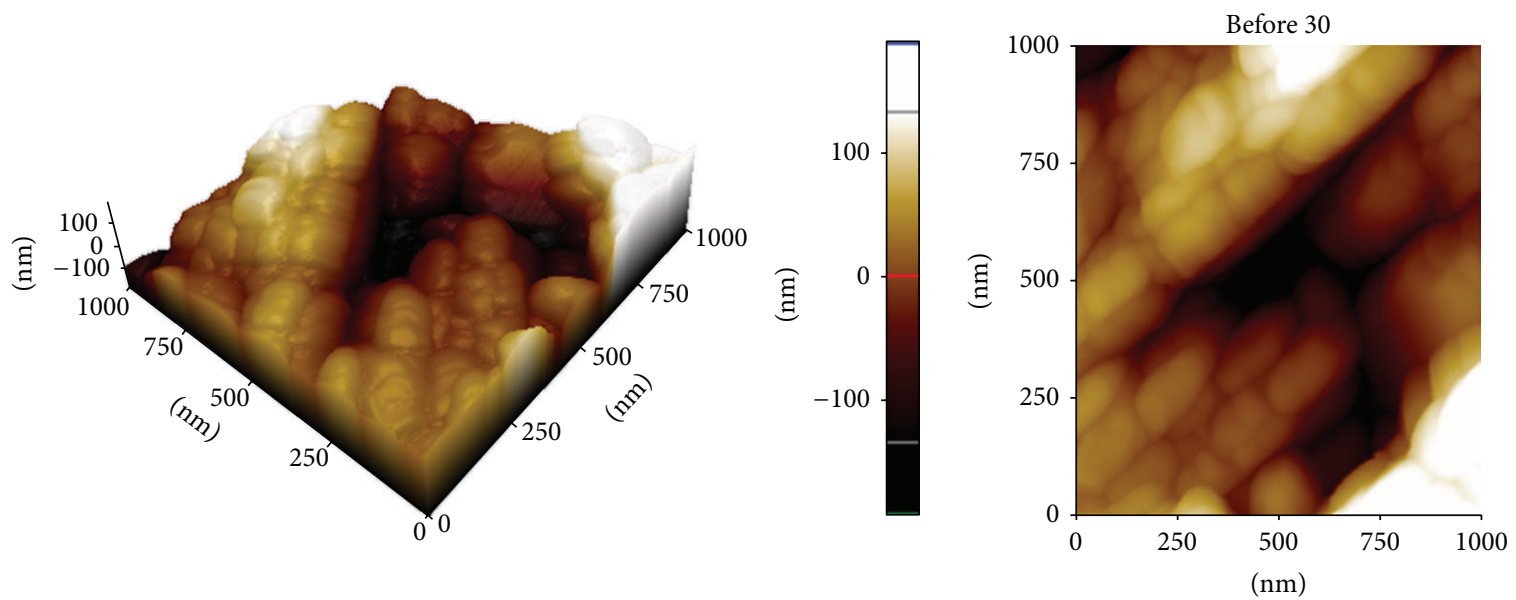

(a)
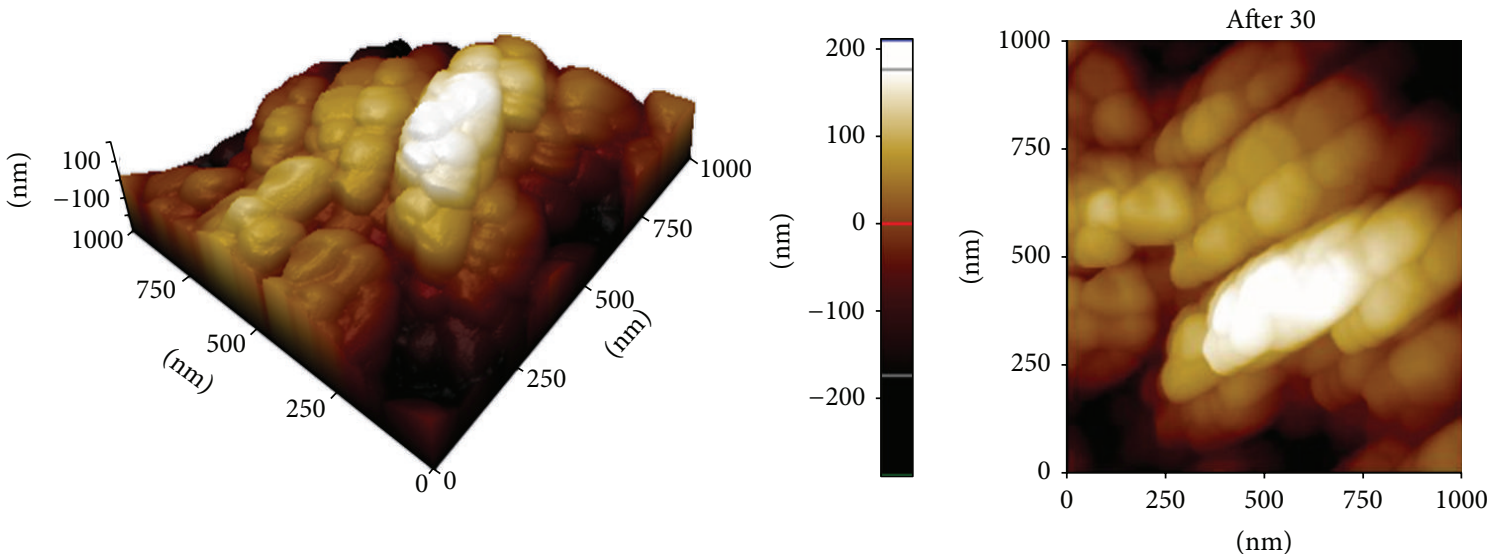

(b)

Figure 6: (a) 3D surface structure of untreated $\mathrm{TiO}_{2}$ film in range of $25 \mu \mathrm{m}^{2}$ along with histogram. (b) $3 \mathrm{D}$ surface structure of treated $\mathrm{TiO}_{2}$ film in range of $25 \mu \mathrm{m}^{2}$ along with histogram.
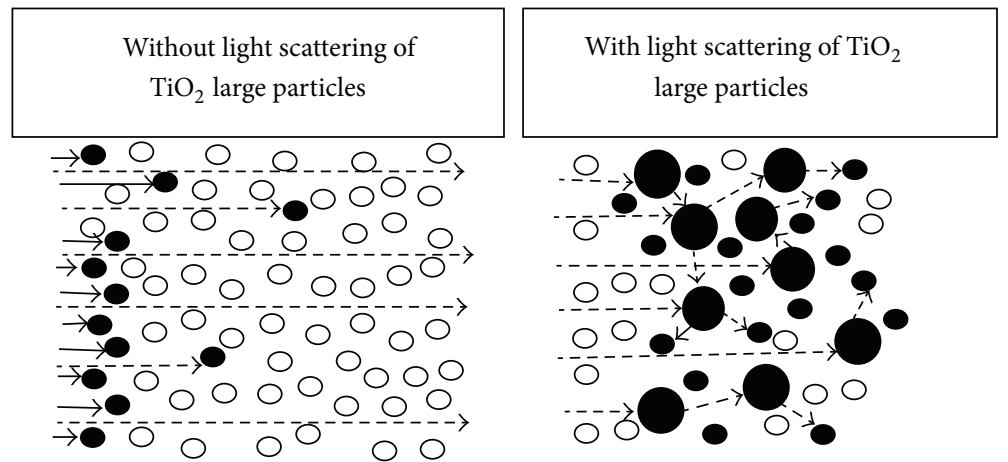

$\longrightarrow$ Short wavelength light

$--\rightarrow$ Long wavelength light

Optical path length of incident light is prolonged by light scattering of large particles

Light scattering of $\mathrm{TiO}_{2}$ large particles $(100-300 \mathrm{~nm})$

FIGURE 7: Light scattering concept depending on particle size of a material reproduced by Attaf [19]. 


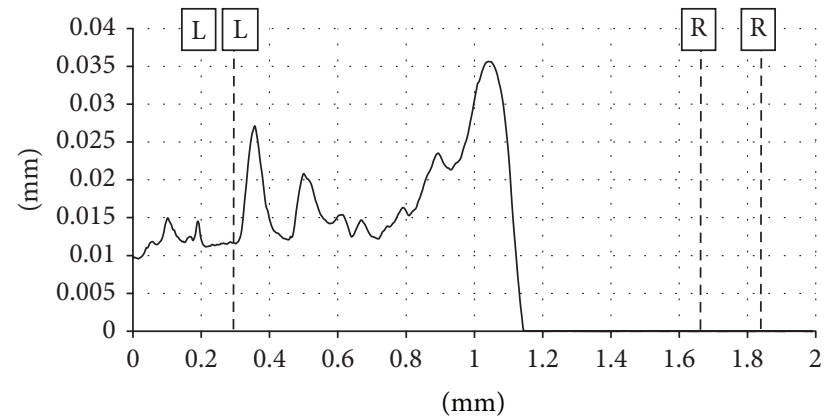

(a)

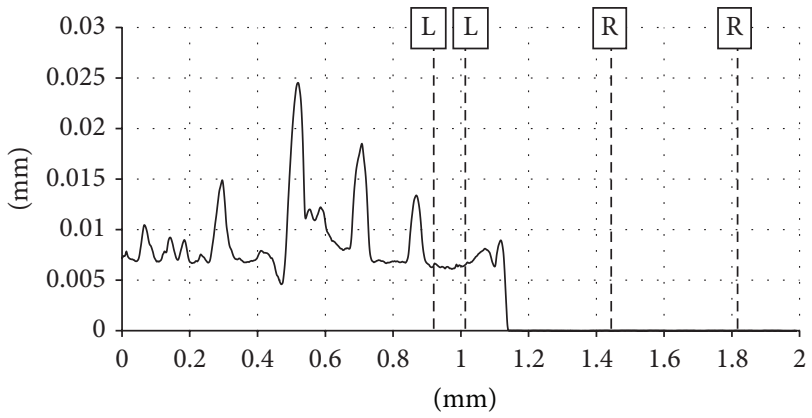

(b)

FIGURE 8: (a) Thickness and surface roughness of untreated $\mathrm{TiO}_{2}$ thin film by Surface Profiler (width $=1567.8 \mu \mathrm{m}$, height $=-11.487 \mu \mathrm{m}$, TIR $=35.649 \mu \mathrm{m}$ ). (b) Thickness and surface roughness of treated $\mathrm{TiO}_{2}$ thin film by Surface Profiler (width $=654.72 \mu \mathrm{m}$, height $=-6.2984 \mu \mathrm{m}$ ).

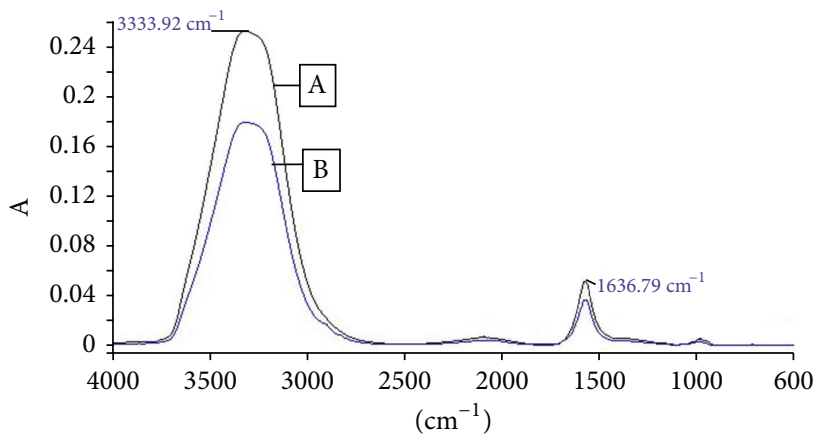

A: commercial blackberry B: local natural dye

FIGURE 9: Functional group comparison between commercial blackberry dye and local natural dye, Senduduk's fruit.

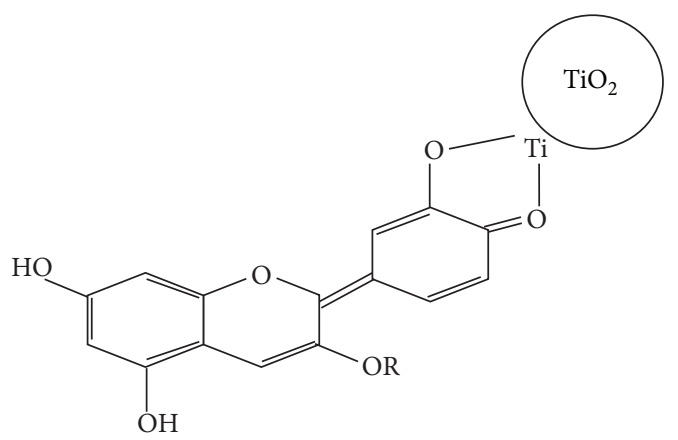

Figure 10: The basic molecular structure of anthocyanin and the binding with $\mathrm{TiO}_{2}$ [5].

where $V_{m}$ is voltage at maximum power point, $I_{m}$ is current at maximum power point, $V_{\mathrm{oc}}$ is open circuit voltage, $I_{\mathrm{sc}}$ is short circuit current, and $P_{\text {in }}$ is power of the incident light.

From Table 2, the open circuit voltage, $\left(V_{\mathrm{oc}}\right)$, for each photovoltaic cell presents interesting values ranging, $0.742 \mathrm{~V}$ for $\mathrm{U} 4,0.732 \mathrm{~V}$ for $\mathrm{U} 1,0.698 \mathrm{~V}$ for $\mathrm{U} 2$, and the lowest $0.335 \mathrm{~V}$ for U3. This voltage order follows their respective efficiencies: $0.039 \%, 0.033 \%, 0.031 \%$ and $0.015 \%$.

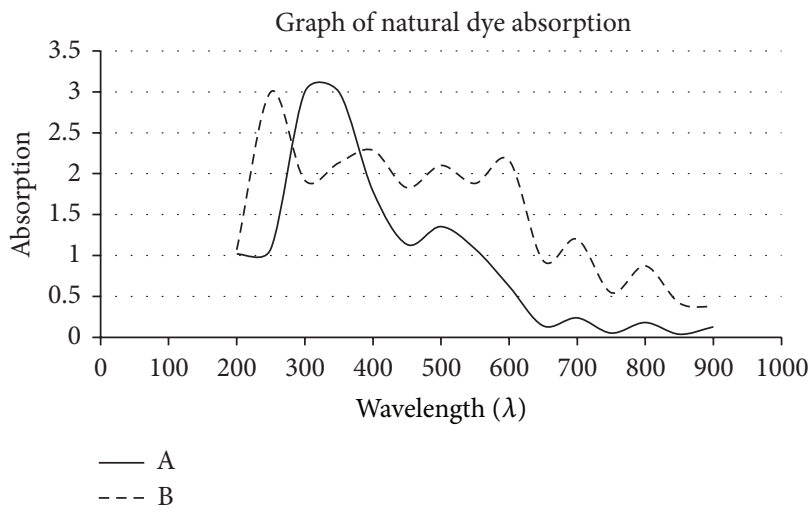

Figure 11: Absorption characteristic of commercial, A, and local natural dye, B.

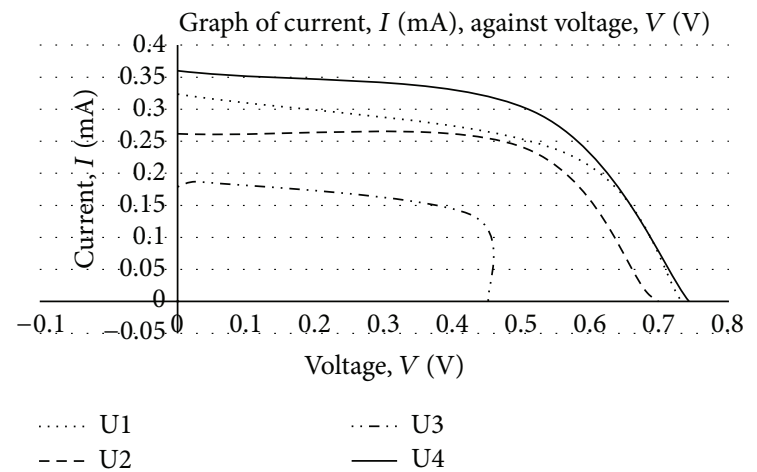

FIGURE 12: Graph of $I-V$ characteristic of photovoltaic solar cell, namely, U1 (without ultrasonic process and no additive), U2 (without ultrasonic process and additive), U3 (ultrasonic process and no additives), and $\mathrm{U} 4$ (ultrasonic process and additive).

Noting that $\mathrm{TiO}_{2}$ particle size in the range of 0.37 $0.15 \mu \mathrm{m}$ and the proposed new natural dye from the extracted Melastoma malabathricum fruit are used in this research, where the data shows a comparable value with $\mathrm{TiO}_{2}$ nanocrystals DSSC using blackberry dye as reported by Tanihaha et al., [2]. Their data recorded as the highest 
TABLE 2: The electrical characterization of all prepared cells.

\begin{tabular}{lcccccccc}
\hline Sample & $V_{\text {oc }}(\mathrm{V})$ & $I_{\text {sc }}(\mathrm{mA})$ & $J_{\text {sc }}\left(\mathrm{mA} / \mathrm{cm}^{2}\right)$ & $I_{\max }(\mathrm{mA})$ & $V_{\max }(\mathrm{V})$ & $P_{\max }(\mathrm{mW})$ & FF & Efficiency $(\eta \%)$ \\
\hline U1 & 0.732 & 0.33 & 0.082 & 0.23 & 0.561 & 0.130 & 54.575 & 0.033 \\
U2 & 0.698 & 0.22 & 0.056 & 0.24 & 0.496 & 0.122 & 77.911 & 0.031 \\
U3 & 0.335 & 0.18 & 0.045 & 0.14 & 0.424 & 0.058 & 96.448 & 0.015 \\
U4 & 0.742 & 0.36 & 0.090 & 0.30 & 0.515 & 0.153 & 57.012 & 0.039 \\
\hline
\end{tabular}

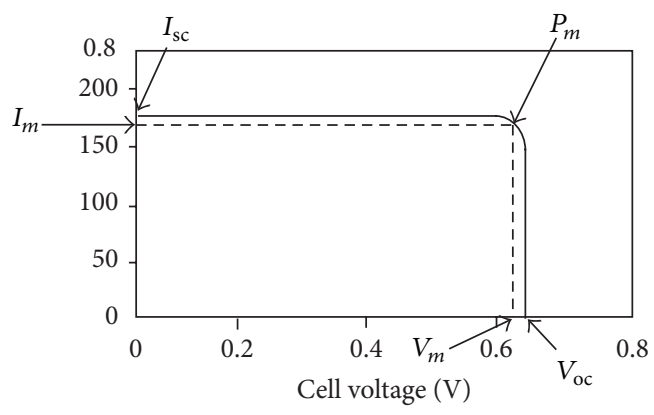

FIgURE 13: $I-V$ characteristics of a typical DSC [20].

efficiency of $0.196 \%$ which decreased to $0.018 \%$ within less than 30 minutes, compared to the present research; the efficiency is between $0.039 \%$ to $0.015 \%$. This is due to the grade of the particle $\mathrm{TiO}_{2}$ and imperfect sealant (using only clipper to assemble both electrode and counter electrode) and the cell being exposed for some time under the light beam before the first data had been recorded. Therefore, in summary the photovoltaic solar cell proposed in this research is comparable to the standard materials.

3.5. Outdoor Stability. Preliminary tests on the stability of Melastoma malabathricum fruit photovoltaic solar cell for four samples (U1, U2, U3, and U4) were carried out upon sunlight illumination, at noon (12-1 pm) and afternoon (3$4 \mathrm{pm}$ ) for several days. The average value of potential $(V)$ obtained for prepared cells is shown as in Figures 14 and 15 , respectively. Based on the bar chart, it is obvious that there is a typical decreasing pattern of average potential $(V)$ values for each photovoltaic cell from day one to day ten. However, the average potential $(V)$ values for $\mathrm{U} 4$ stand in its own class either at noon or in the afternoon where the values were slightly higher and more stable due to the beneficial characteristics of the additive.

The performance of photovoltaic solar cell is more extrinsicaly related to the grade of $\mathrm{TiO}_{2}$ and is due to imperfect sealant. Knowing that Malaysia is an equatorial country, sunny and rainy throughout the year with high humidity and a cloudy sky, so the performance of the photovoltaic solar cell can be easily affected, in which there is usually little or no direct sunlight. As the sunlight is blocked by the clouds or reflect off of other objects, it is experienced as diffused light, which causes variation in colors and intensity. This makes the calculation of photovoltaic solar cell efficiency slightly different from the theory as both cells have different particle sizes with different advantages. Explaining the electrons

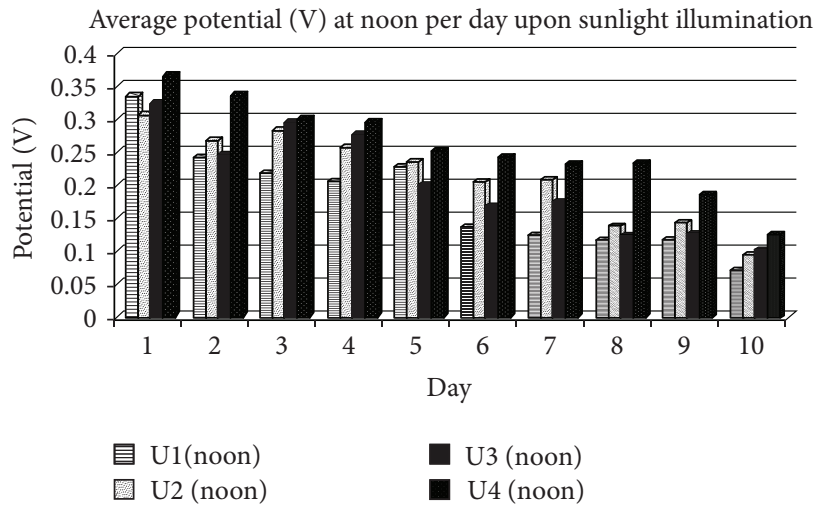

FIGURE 14: Graph of the average values of potential (V) at noon (12$1 \mathrm{pm}$ ) upon sunlight illumination for ten days where respective cell; metal oxide; U1 and U2 (without and with additive, resp.), treated metal oxide with ultrasonic; U3 and U4 (without and with additive, resp.).

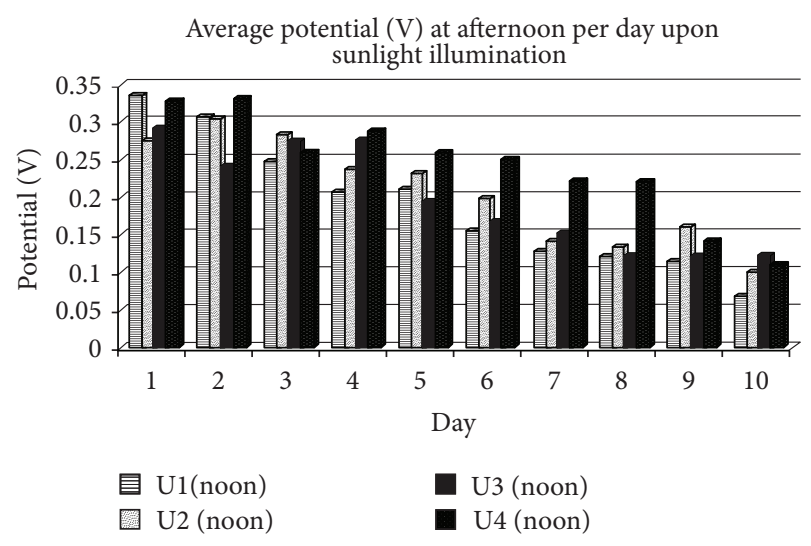

FIGURE 15: Graph of the average values of potential (V) at afternoon (3-4 pm) upon sunlight illumination for ten days where respective cell; metal oxide; U1 and U2 (without and with additive, resp.), treated metal oxide with ultrasonic; U3 and U4 (without and with additive, resp.).

detrap and trap events, under low light intensity, the electrons which are trapped deep inside the $\mathrm{TiO}_{2}$ film will take longer time be to detrapped by thermal activation and to reach the TCO glass where by influencing electron diffusion and lifetime and it goes vice versa for high light intensity.

In most of the researches on DSSCs, typical sealants being used are Surlyn and glass frit. However, due to its high fabrication cost, a simple clip was used to assemble the electrode and counter electrode together in this research. This simple 
technique resulted in imperfect sealant or electrode/counter electrode holder that caused the photovoltaic solar cell facing stability problems such as the leakage and volatilization of the mixed $\mathrm{KI} / \mathrm{I}_{2}$ electrolytes. As the electrolyte $\mathrm{KI} / \mathrm{I}_{2}$ plays an important role in the process of photon-convert electricity in DSC, therefore, there is a need to constantly adding the $\mathrm{KI} / \mathrm{I}_{2}$ electrolyte (solution) to the cell to ensure the cell performance.

As for intrinsic factors, aforementioned that the air consists of high humidity which directly jeopardized the catalyst, dye sensitizer, liquid electrolyte, and overall photovoltaic solar cell performance, and this is due to impurities. Impurities also occur during fabrication, either while mixing, sintering, or assembling. Theoretically, instead of impurities, defects such as oxygen and metal vacancies inside the $\mathrm{TiO}_{2}$ film always come into picture.

\section{Conclusion}

The assembled dye solar cell comprises three-layer structure of engineering grade ( $>99 \%$ purity) metal oxide as photoelectrode, a novel natural dye from Melastoma malabathricum as sensitizer, liquid electrolyte as the electron donor, and carbon black as counter electrode. An original particle size and agglomeration of $\mathrm{TiO}_{2}$ have been reduced from $0.37 \mu \mathrm{m}$ to $0.15 \mu \mathrm{m}$, respectively, upon 10 minutes via ultrasonic process therefore causing reduction in $\mathrm{TiO}_{2}$ thin-film thickness. Finer and denser particles distribution morphology is evidently shown by FE-SEM and AFM which contributes to high porosity. These respective DSCs, untreated metal oxide with ultrasonic process, U1 and U2, and treated metal oxide with ultrasonic process, U3 and U4, give $0.033 \%, 0.031 \%, 0.015 \%$, and the highest $0.039 \%$ efficiencies, respectively. The first encouraging outdoor test upon sunlight illumination shows that the cell can be improved and designed into a complete solar module/panels in order to be used in real application.

\section{Acknowledgments}

One of the authors would like to thank Universiti Tun Hussein Onn Malaysia (UTHM), Johor, and Malaysian Government for supporting this research under Fundamental Research Grant Scheme (Phase 1/2012), vot 1047.

\section{References}

[1] K. Tennakone, G. R. R. A. Kumara, A. R. Kumarasinghe, P. M. Sirimanne, and K. G. U. Wijayantha, "Efficient photosensitization of nanocrystalline $\mathrm{TiO}_{2}$ films by tannins and related phenolic substances," Journal of Photochemistry and Photobiology A, vol. 94, no. 2-3, pp. 217-220, 1996.

[2] S. L. Tanihaha, H. P. Uranus, and J. Darma, "Fabrication and characterization of dye-sensitized solar cell using blackberry dye and titanium dioxide nanocrystals," in Proceedings of the 2nd International Conference on Advances in Computing, Control and Telecommunication Technologies (ACT '10), pp. 6063, December 2010.

[3] G. Calogero and G. D. Marco, "Red Sicilian orange and purple eggplant fruits as natural sensitizers for dye-sensitized solar cells," Solar Energy Materials and Solar Cells, vol. 92, no. 11, pp. 1341-1346, 2008.

[4] W. Khwanchit, M. Vissanu, and C. Sumaeth, "Dye-sensitized solar cell using natural dyes extracted from rosella and blue pea flowers," Solar Energy Materials and Solar Cells, vol. 91, no. 7, pp. 566-571, 2007.

[5] S. Hao, J. Wu, Y. Huang, and J. Lin, "Natural dyes as photosensitizers for dye-sensitized solar cell," Solar Energy, vol. 80, no. 2, pp. 209-216, 2006.

[6] G. Calogero, J.-H. Yum, A. Sinopoli, G. Di Marco, M. Gratzel, and M. K. Nazeeruddin, "Anthocyanins and betalains as light harvesting pigments for dye sensitized solar cells," Solar Energy, vol. 86, pp. 1563-1575, 2012.

[7] G. Calogero, G. Di Marco, S. Caramori, S. Cazzanti, R. Argazzi, and C. A. Bignozzi, "Natural dye senstizers for photoelectrochemical cells," Energy and Environmental Science, vol. 2, no. 11, pp. 1162-1172, 2009.

[8] Z. Liu, "Theoretical studies of natural pigments relevant to dyesensitized solar cells," Journal of Molecular Structure, vol. 862, no. 1-3, pp. 44-48, 2008.

[9] M. R. Hoffmann, S. T. Martin, W. Choi, and D. W. Bahnemann, "Environmental applications of semiconductor photocatalysis," Chemical Reviews, vol. 95, no. 1, pp. 69-96, 1995.

[10] U. Diebold, "The surface science of titanium dioxide," Surface Science Reports, vol. 48, no. 5-8, pp. 53-229, 2003.

[11] K. Sumandeep, Light Induced Oxidative Degradation Studies of Organic Dyes and Their Intermediates [Ph.D. thesis], Thapar University, 2007.

[12] H. B. Jin and K. S. Suslick, "Applications of ultrasonic to the synthesis of nanostructured materials," Advanced Materials, vol. 22, no. 10, pp. 1039-1059, 2010.

[13] Gordillo G. and X. Hailey, "Nanopowder production: a comparison of several methods," Project Report NSF-REU, 2004.

[14] N. Mandzy, E. Grulke, and T. Druffel, "Breakage of $\mathrm{TiO}_{2}$ agglomerates in electrostatically stabilized aqueous dispersions," Powder Technology, vol. 160, no. 2, pp. 121-126, 2005.

[15] M. R. Hoffmann, S. T. Martin, W. Choi, and D. W. Bahnemann, "Environmental applications of semiconductor photocatalysis," Chemical Reviews, vol. 95, no. 1, pp. 69-96, 1995.

[16] K. E. Lee, C. Charbonneau, G. Shan, G. P. Demopoulos, and R. Gauvin, "Nanocrystalline $\mathrm{TiO}_{2}$ thin film electrodes for dyesensitized solar cell applications," JOM, vol. 61, no. 4, pp. 52-57, 2009.

[17] K. Agarwal and K. Ghaziabad, European Patent Application EP0754734A1, 2009.

[18] V. Sundström, Ed., "Solar energy conversion," Dalton Transactions, no. 45, 2009.

[19] B. Attaf, Ed., Advances in Composite Materials for Medicine and Nanotechnology, 2011.

[20] K. Takechi, R. Muszynski, and P. V. Kamat, "Fabrication procedure of dye-sensitized solar cells," 2009, http://www3 .nd.edu/pkamat/pdf/solarcell.pdf.

[21] M. K. Ahmad, M. L. M. Halid, N. A. Rasheid et al., "Effect of annealing temperatures on surface morphology and electrical properties of titanium dioxide thin films prepared by sol gel method," Journal of Sustainable Energy and Environment, vol. 1, pp. 17-20, 2010.

[22] A. Tholvanen, Characterization and manufacturing technique of dye-sensitized solar cell [M.S. thesis], Helsinki University of Technology, 2003. 
[23] L. Han, T. Obata, and Y. Inoue, "Photoelectric material using organic photosensitising dyes and manufacturing method thereof," U.S. Patent 6, 2000.

[24] I. Konczak and W. Zhang, "Anthocyanins: more than nature's colours," Journal of Biomedicine and Biotechnology, vol. 2004, no. 5, pp. 241-242, 2004.

[25] D. Susanti, H. M. Sirat, F. Ahmad, and M. Ali, "Bioactive constituents from the leaves of Melastoma malabathricum L.," Jurnal Ilmiah Farmasi, vol. 5, pp. 1-8, 2008.

[26] C. T. Yip, Effect of morphologies and electronic properties of metal oxide nanostructure layer on dye sensitized solar cells [Ph.D. thesis], The University of Hong Kong, 2010.

[27] M. M. Giusti and R. E. Wrolstad, Current Protocols in Food Analytical Chemistry, John Wiley and Sons, 2001. 

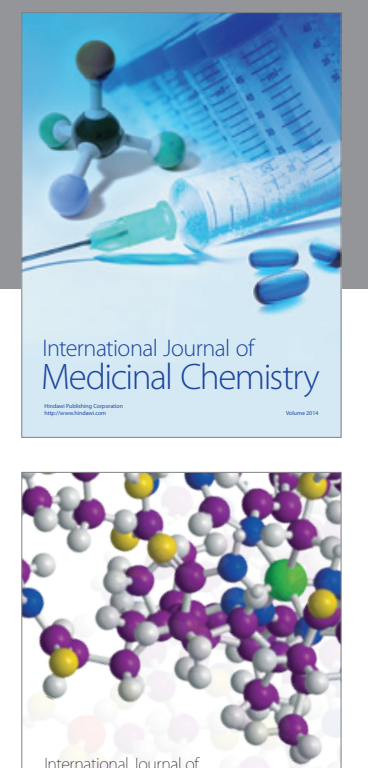

\section{Carbohydrate} Chemistry

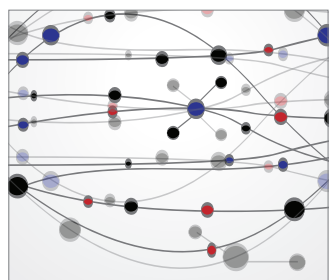

The Scientific World Journal
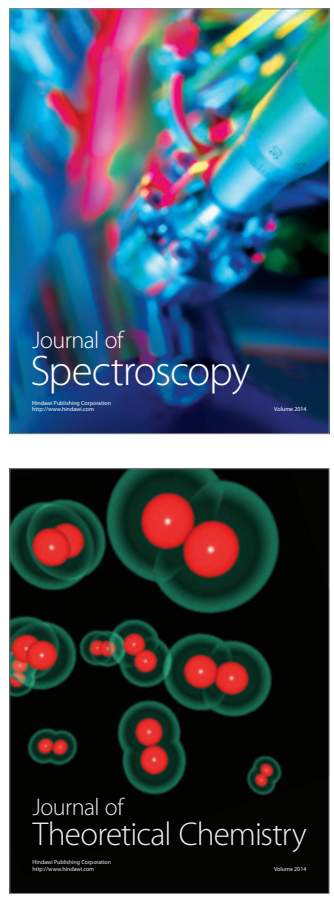
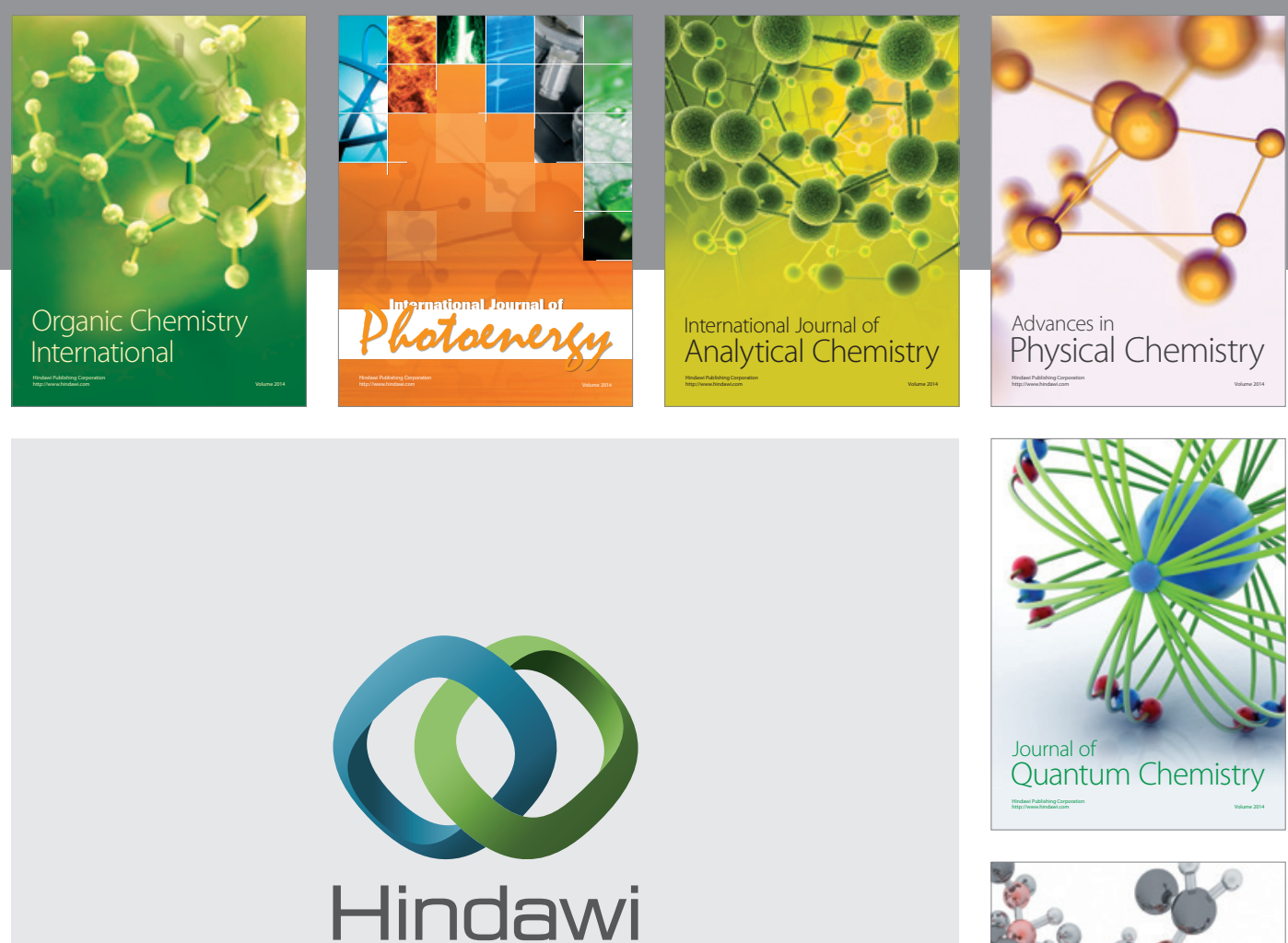

Submit your manuscripts at

http://www.hindawi.com

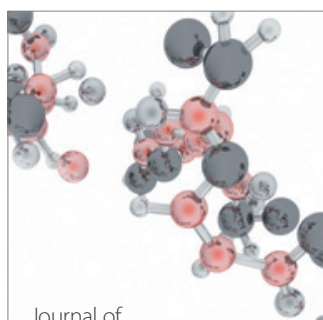

Analytical Methods

in Chemistry

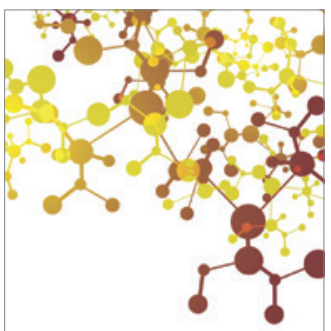

Journal of

Applied Chemistry

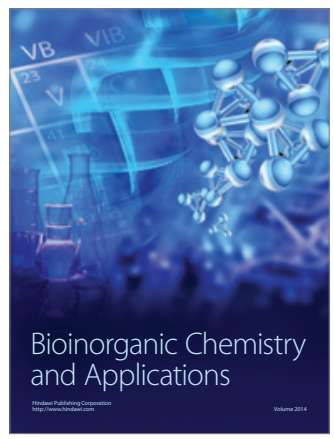

Inorganic Chemistry
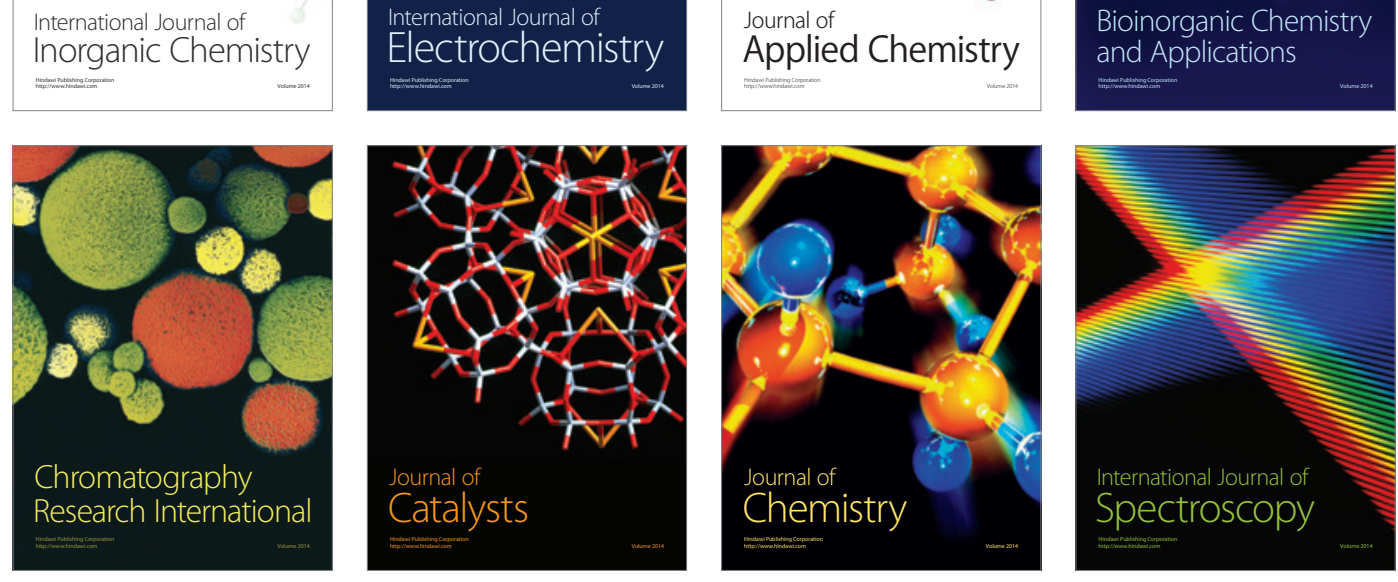